DOI https://doi.org/10.36059/978-966-397-210-7/257-282

\author{
Лотюк О. C., \\ доктор юридичних наук, професор, \\ професор кафедри конституційного права \\ Київського національного університету \\ імені Тараса Шевченка, \\ м. Київ
}

Митник О. В.,

аспірантка кафедри конституційного права

Київського національного університету

імені Тараса Шевченка,

керівник експертної групи з прав людини

Директорату стратегічного планування

та європейської інтеграції

Міністерства юстиції України,

м. Київ

\title{
ГЕНЕЗИС МЕХАНІЗМУ СУДОВОГО ЗАХИСТУ КОНСТИТУЦІЙНИХ ПРАВ ЛЮДИНИ
}

Анотація. Судовий захист конституційних прав людини розглядається як одна з моделей захисту конституційних прав людини через призму виконання державою своїх універсальних зобов'язань щодо прав людини.

у дослідженні здійснено аналіз історичного розвитку ідеї прав людини та охарактеризовано різні підходи щодо їх тлумачення та типологізації. Наголошується, що процес утвердження прав людини супроводжується зміною парадигми відносин людина - держава, що і визначатиме в подальшому розвиток системи судового захисту конституційних прав людини. Виникнення національних режимів захисту прав людини пов'язується з виникненням перших декларацій прав людини (кінець $18 \mathrm{~cm}$.), досліджуються 
Права людини в Україні та у зарубіжних країнах:

проблеми теорії та нормативно-правової регламентації

легітимні обов'язки держави щодо прав людини: позитивні (утверджувати, захищати права людини) та негативні (утримуватися від порушень прав людини). Як результат прийняття ключових міжнародних документів у сфері прав людини (міжнародні стандарти прав людини), досліджується процес універсалізації зобов'язань держав щодо захисту прав людини та створення міжнародних і регіональних режимів захисту прав людини. Таким чином, автори доходять висновку про виникнення, поряд із національними, універсальних зобов'язань держави щодо прав людини: не порушувати, захищати та сприяти реалізації прав і свобод. Саме 3 обов'язком держави захищати права людини пов'язується існування судового механізму захисту конституційних прав $i$ свобод.

Авторами дослідження описано чотири етапи розвитку механізму судового захисту конституційних прав людини через призму генезису та становлення ідеї прав людини. 3 огляду на множинну правову природу судового захисту зазначену категорію розглянуто як основоположне право; гарантію основоположних прав; ефективний засіб захисту; механізм захисту прав людини. Надано авторське визначення механізму судового захисту конституційних прав людини та виокремлено його основні ознаки. Автори також окреслили власне бачення перспективних напрямів дослідження механізму судового захисту конституційних прав з огляду на його подальшу трансформацію у зв'язку з інтеграційними та глобалізаційними процесами, а також у контексті цифровізації доступу до правосуддя.

\section{Вступ}

Із часу прийняття ключових міжнародних документів у сфері прав людини проблема реалізації правозахисної функції держави не втрачає своєї актуальності. Питання парадигми відносин «людина - держава» та ролі держави у захисті конституційних прав людини тривалий час $\epsilon$ предметом дискусії філософів, правників, теоретиків та практиків. 
Відтак тематика прав людини, функціонування режимів ïx захисту достатньо широко досліджена у працях як українських науковців (П. Рабіновича, С. Шевчука, С. Головатого, О. Марцеляка, М. Савчина, О. Васильченко, М. Орзіха, М. Козюбри, В. Буткевича, В. Кампа, В. Шишкіна, Н. Карпачової, Ю. Тодики, М. Гнатовського та ін.), так i представників іноземних правничих шкіл: Т. Пейна, Б. Таманаги, П. Гаудера, Л. Свендсена, Ш. Госепата, Г. Ломанна, Р. Дворкіна, Г. Харта, О. Гьоффе, Л. Фуллера, М. Манукяна та ін. Філософія та сутність судового захисту знайшли свої відображення у роботах В. Бігуна, Б. Малишева, С. Шевчука, О. Лемак. Водночас витоки становлення ідеї судового захисту прав людини містяться у класичних роботах філософсько-правової та політичної думки, зокрема працях Аристотеля, Цицерона, Платона, Ж.-Ж. Руссо, I. Канта, Т. Гоббса, Ш. Монтеск'є, Г. Гроція, Т. Джеферсона та ін.

Хоча прийнято вважати, що судовий захист $є$ однією 3 найефективніших моделей захисту прав людини, це не убезпечує від фактів порушень основоположного права людини на доступ до суду. Зокрема, як свідчить статистика рішень Європейського суду з прав людини (далі - ЄСПЛ), близько 40\% порушень, констатованих Судом, стосуються статті 6 Європейської конвенції із прав людини (далі ЄКПЛ, Конвенція), а саме справедливого судового розгляду (16,86\%) та тривалості процедур $(21,41 \%)$ [33]. Це ілюструє необхідність пошуку більш ефективних механізмів судового захисту конституційних прав і свобод людини та вдосконалення тих механізмів, які існують, відповідно до загальновизнаних норм і стандартів.

Водночас задля пошуку найбільш оптимальних шляхів вдосконалення механізму судового захисту конституційних прав людини, на наше переконання, важливо дослідити генезис та правову природу такого механізму та надати відповідь на засадничі питання щодо сутності судового захисту прав людини та його втілення в національних, регіональних та міжнародному режимах прав людини, трансформації ролі суду в загальній системі 
Права людини в Україні та у зарубіжних країнах:

проблеми теорії та нормативно-правової регламентації

захисту прав людини. У цьому контексті важливо дослідити процес становлення концепції судового захисту конституційних прав людини через призму виконання державою зобов'язань щодо прав людини, здійснити періодизацію розвитку механізму судового захисту конституційних прав людини.

\section{1. Розвиток ідеї прав людини та становлення}

\section{концепції захисту конституційних прав людини}

Починаючи 3 часів античності філософи, юристи, правозахисники намагаються зрозуміти сутність прав людини, віднайти найкращі інструменти для їх втілення. Перефразувавши думку I. Канта, який зауважує: «Питання про те, що таке право, становить для юриста таку ж складність, як і для логіки питання, що таке істина» [9, с. 10], можна стверджувати те ж саме і про права людини. Водночас необхідність єдиного, універсального тлумачення прав людини не $\epsilon$ проблемою суто теоретичною чи філософською, а має конкретне практичне значення. Так, від розуміння вихідних понять залежить, які права захищати і хто є суб'єктом прав, чи існують поряд із класичними індивідуальними правами людини також «колективні» права людини, як визначається носій прав i хто $\epsilon$ адресатом відповідних обов'язків [27, с. 18].

Намагаючись здійснити певне розмежування, Отфрид Гьоффе надає таку типологію прав людини: «Там, де ми говоримо про суб'єктивні права, маючи на увазі громадянина, що належить до певного правового та державного устрою, ми говоримо про основні права. Проте інститут права (суб'єктивного) має глибшу основу: людина висуває вимоги на «вроджені» (природні) права тільки тому, що вона людина, а це означає - незалежно від інституту держави. Отже, під правами людини слід розуміти права, що належать людині, як людині, тоді як під основними правами - елементарні права кожного громадянина держави» [12, с. 34]. У цілому підтримуючи вищезгадану ідею, зазначимо, що дослідження генезису 
становлення ідеї прав людини дає змогу чітко прослідкувати трансформацію прав людини із природних (основоположних, універсальних) у конституційні права.

Витоки універсалізму прав людини можна простежити ще в мислителів античності. Так, встановлюючи різницю між природньою та соціальною справедливістю, Аристотель пише, що природня справедливість не залежить від того, погоджуються з нею чи ні, має однакову цінність всюди, долає кордони соціальних і політичних систем. Ж.-Ж. Руссо, відстоюючи принцип невідчужуваності прав людини у державі, зазначає, що «людина народжується вільною, але всюди вона в кайданах» [5, с. 315]. У розумінні Локка всі люди народжуються вільними й рівноправними, вони мають певні права, які дійсні незалежно від позитивних законів у різних суспільствах [28, с. 220].

У «Декларації незалежності 1776 року», одним із ідеологів якої був Т.Джефферсон, зазначено: всі люди створені рівними, наділеними Творцем визначеними невід'ємними правами, серед яких право на життя, свободу та щастя; для забезпечення цих прав серед людей існують уряди, які здійснюють свою владу зі згоди тих, ким вони управляють; якщо форма правління стає згубною, народ має право змінити або відмінити ії, і встановити владу в такій формі, яка б найкраще захищала б його безпеку i добробут. Трохи пізніше, в 1787 році, була прийнята Конституція США, перші 10 поправок до якої («Білль про права») містили положення, які поєднували принципи Великої хартії вольностей та ідеї філософів-просвітників [9, с. 18].

Велика французька революція 1789 року також увібрала в себе ідею невідчужуваних природних прав людини та досвід американських батьків-засновників. Так, Декларація містила цікаві 3 точки зору прав людини положення: «Люди народжуються і залишаються вільними і рівними у правах; суспільні відмінності можуть ґрунтуватися лише на основі загальної користі. Метою кожного політичного 
об'єднання є збереження природних і невід'ємних прав людини; цими правами є свобода, власність, безпека і опір гніту. Усяке суспільство, в якому не забезпечуються гарантії прав або не проведено розподілу влад, не має конституції взагалі» [30].

У зв'язку із цим Отфрид Гьоффе звертає увагу на те, що перші декларації прав людини (напр. французька Декларація прав людини і громадянина 1789 року) формулюють «переддержавні права» (природні права прим. автора), тобто такі, що $є$ дійсними до існування держави. Лише потім держава як втілення суспільної влади отримує легітимацію щодо прав людини (курсив - наш)1. Перед державою стоїть завдання сприяти реалізації, або ж гарантувати їх [12, с. 34].

Так виникають національні режими захисту прав людини, а природні права отримують визнання державами та формальне закріплення у конституціях, тобто стають конституційними. Цей процес супроводжується зміною парадигми відносин людина - держава, що і визначатиме в подальшому розвиток системи захисту прав людини.

Цілком доречно в цьому випадку говорити про виникнення легітимних обов'язків держави щодо прав людини: позитивних (утверджувати, захищати) та негативних (утримуватися від порушень). Ці зобов'язання мали свої особливості, що полягали, по-перше, в існуванні монополії держави в питаннях захисту прав своїх громадян. По-друге, вже 3 часу прийняття перших декларацій прав людини дуже чітко прослідковується подвійна природа зобов'язань держави щодо людини: 3 одного боку, держава - це суб'єкт, який через систему відповідних органів зобов'язаний гарантувати, захищати права, з іншого боку, держава є таким самим суб'єктом, на який поширюється обов'язок утримуватися від порушень прав (що є запереченням принципу "nemo debet esse iudex

1 Очевидно, в цьому випадку йде мова про «державні», конституційні права. 
Права людини в Україні та у зарубіжних країнах:

проблеми теорії та нормативно-правової регламентації

in propria causa"). Для того аби принцип «ніхто не може бути суддею у власній справі» було дотримано в питаннях, коли порушником виступає власне держава, зі створенням міжнародного режиму захисту прав людини концепція правосуддя набула нового змісту.

Універсалізація зобов'язань держав щодо захисту прав людини. Питання про те, яким чином найкраще реалізувати правозахисну, правоутверджувальну i правозабезпечувальну функції держави, набуло нового значення після прийняття ключових міжнародних документів у сфері прав людини (т.зв. міжнародні стандарти прав людини) $)^{2}$. Існування цих стандартів заклали підвалини функціонування міжнародного режиму захисту прав людини.

Поступово, окрім міжнародних, утворюються регіональні режими захисту прав людини ${ }^{3}$ (Європейський, Міжамериканський, Африканський, Азійський тощо). Ці режими також характеризуються наявністю певних стандартів із прав людини (Європейська конвенція з прав людини, Хартія Основних прав $€ C$, Міжамериканська конвенція 3 прав людини, Африканська хартія прав людини та народів, Декларація прав людини Асоціації держав Південно-Східної Азії тощо).

Для того аби імплементувати ці режими (міжнародний та регіональні правові режими - прим. авторів), в останні десятиліття були створені різні міжнародні та регіональні трибунали, зокрема Міжнародний суд (Світовий суд),

2 Див. Статут Організації Об’єднаних Націй, Загальна декларація прав людини, Міжнародний пакт про громадянські і політичні права, Міжнародний пакт про соціальні, економічні та культурні права, Конвенція про захист прав людини і основоположних свобод.

3 Детальніше про регіональні режими захисту прав людини див. Шуміло І.А. Міжнародна система захисту прав людини : навчальний посібник / І. А. Шуміло. Київ : ФОП Голембовська О.О., 2018. 168 с. Манукян В.И. Международная защита прав человека: право, прецеденты, комментарии: Научно-практическое пособие. Київ : Истина, 2010. 480 с. 
Права людини в Україні та у зарубіжних країнах:

проблеми теорії та нормативно-правової регламентації

Міжнародний трибунал із морського права, Суд $Є C$, Центральноамериканський суд, Європейський суд із прав людини, Міжамериканський суд із прав людини, Трибунали військових злочинів колишньої Югославії та Руанди, Міжнародний кримінальний суд та інші [29, с. 127].

Згодом положення Загальної декларації прав людини та інших міжнародних стандартів органічно знайшли своє відображення в конституції майже кожної держави, і саме держава відтоді визнається відповідальною за ефективну реалізацію функції захисту прав людини. Так, у 1993 році на Світовій конференції із прав людини було прийнято Віденську декларацію та програму дій, в якій зазначено: «Усі права людини $є$ універсальними, неподільними та взаємозалежними та взаємопов'язаними... Незважаючи на значення національних та регіональних особливостей та різних історичних, культурних та релігійних обставин, обов'язком держав, незалежно від їх політичної, економічної та культурної систем, $\epsilon$ сприяти і захищати усі права людини та основоположні свободи... Права людини та основоположні свободи належать усім людям від народження; їх захист та просування - це найперша відповідальність урядів» (курсив - авторів) [34].

Ця теза знайшла відображення i в практиці Конституційного суду України. Зокрема, в одному з рішень Конституційний Суд України зазначив, що держава, виконуючи свій головний обов'язок - утвердження i забезпечення прав і свобод людини (частина друга статті 3 Конституції України) - повинна не тільки утримуватися від порушень чи непропорційних обмежень прав і свобод людини, але й вживати належних заходів для забезпечення можливості їх повної реалізації кожним, хто перебуває під ії юрисдикцією. Із цією метою законодавець та інші органи публічної влади мають забезпечувати ефективне правове регулювання, яке відповідає конституційним нормам i принципам, та створювати механізми, необхідні для задоволення потреб та інтересів людини (абзац перший пункту 3 мотивувальної частини ) [17]. 
Таким чином, поряд із національними виникають універсальні зобов'язання держави щодо прав людини. Характер таких зобов'язань можливо дослідити через аналіз положень Міжнародного пакту про громадянські та політичні права (далі - Міжнародний пакт).

Перше зобов'язання держави - поважати i забезпечувати всім, хто перебуває в межах їі території та знаходиться під їі юрисдикцією, права, визнані в цьому Пакті, без будь-якої різниці щодо раси, кольору шкіри, статі, мови, релігії, політичних чи інших переконань, національного чи соціального походження, майнового стану, народження чи іншої обставини [10]. Ці дві складові частини вищезгаданого зобов'язання - поважати i забезпечувати - можна розтлумачити таким чином.

Держава виконує зобов'язання «поважати» визнані права, не порушуючи їх. Кожного разу, коли державний орган, службова особа чи державна організація порушує право, виникає невиконання обов'язку поважати це право. Порушення права, яке було здійснено не безпосередньо державою (наприклад, тому, що це вчинок приватної особи або тому, що відповідальна особа не була визначена), також може визнати неспроможність держави «поважати» право, проте не через сам факт порушення, а через відсутність належних заходів для запобігання порушенню чи реагування на нього [32, с. 46].

«Забезпечувати» означає обов'язок держави організувати урядовий апарат i, як правило, всі структури, за допомогою яких реалізується державна влада, таким чином, щоб вільне та повне використання цих прав було забезпечено. Тобто повинні існувати механізми, за допомогою яких держава може запобігти, розслідувати та покарати будь-яке порушення права i, якщо це можливо, відновити порушене право (курсив - авторів) та надати таку компенсацію, яка може бути гарантована за будь-яку шкоду, спричинену порушенням. Держава також несе юридичний обов'язок запобігати порушенню прав людини та використовувати засоби, які вона має, для проведення 
грунтовного розслідування порушень, вчинених у межах іiі юрисдикції, для виявлення порушників, призначення відповідного покарання та забезпечення компенсації потерпілій особі [32, с. 46-47].

Друге зобов'язання держави за Міжнародним пактом відповідно до своїх конституційних процедур вжити необхідних заходів для реалізації визнаних прав.

Третє зобов'язання - забезпечити ефбективний засіб захисту. Суть цього зобов'язання полягає в тому, щоб будь-яка особа, права чи свободи якої порушені, мала ефективний засіб захисту, незважаючи на те, що порушення було вчинено особами, які діють від імені держави; гарантувати, що будь-яка особа, яка вимагає такий засіб захисту, має своє право на це визначене компетентними судовими (курсив - авторів), адміністративними чи законодавчими органами чи правовою системою, а також розвивати можливості судового перегляду; та забезпечити, щоб компетентні органи надавали такі гарантовані засоби правового захисту [10]. Аналогічні зобов'язання беруть на себе держави, які $\epsilon$ сторонами ЄКПЛ (стаття 13).

Розглядаючи питання компенсацій за порушення державою прав людини, М. Гнатовський виокремлює також зобов'язання забезпечити відповідність національного законодавства міжнародно-правовим зобов'язанням (включення міжнародних норм у галузі прав людини до їхнього національного законодавства або їх застосування іншим чином у рамках національної правової системи; вжиття необхідних ефективних законодавчих i адміністративних процедур та інших відповідних заходів, що забезпечують на справедливих умовах ефективний і негайний доступ до правосуддя; забезпечення адекватних, ефективних, швидких i належних засобів правового захисту, включно із відшкодуванням тощо) [4, с. 7].

Загалом же виокремлюють 3 ключові зобов'язання держав щодо прав людини: не порушувати, захищати 
та сприяти реалізації прав і свобод. Саме з обов'язком держави захищати права людини і пов'язують існування судового механізму захисту конституційних прав i свобод.

\section{2. Правова природа та сучасне розуміння механізму судового захисту конституційних прав людини.}

\section{1. Становлення концепції судового захисту конституційних прав людини}

Від початку підгрунтям для створення незалежного суду стала теорія розподілу влад та захисту від свавілля держави. Зокрема, М. Савчин зауважує, що запровадження правосуддя здійснюється з метою запобігання свавіллю виконавчої влади. Судовий контроль за актами діями/бездіяльністю публічної адміністрації $\epsilon$ важливим елементом верховенства права та забезпечення поваги до прав людини [24, с. 253].

У Висновку № 1 (2001) Консультативної ради європейських суддів для Комітету міністрів Ради Європи про стандарти незалежності судових органів та незмінюваність суддів зазначається, що судова влада $\epsilon$ однією із трьох рівних засад сучасної демократичної держави. Судова влада відіграє важливу роль та виконує серйозні завдання стосовно двох інших засад. Ця влада забезпечує відповідальність урядів та органів державного управління за свої дії, а також, щодо законодавчої влади, судова влада бере участь у процесі виконання відповідним чином прийнятих законів та більшою чи меншою мірою в тому, щоб забезпечити відповідність цих законів усім положенням Конституції чи права більш високого рівня (як, наприклад, права Європейського союзу) [2].

Водночас нині науковці починають досліджувати захист прав людини як ключову роль суду. Так, В. Бігун розглядає зміст правосуддя як судовий захист права, яким називає «правозахисний смисл правосуддя» [1]. Б. Малишев, наприклад зазначає про процедуру здійснення функції 
судової влади, до якої належать: розгляд справ, захист прав і свобод людини і громадянина, охорона конституційного ладу $[8$, с. 24, 26].

На наше переконання, дослідження сутності судового захисту конституційних прав доцільно розглядати саме через призму відносин людина - держава, в контексті виконання державою своїх універсальних зобов'язань захищати права людини. Водночас в першу чергу на становлення ідеї щодо захисту конституційних прав як функції суду вплинув розвиток концепції прав людини. Відтак у зв'язку зі зміною розуміння прав людини та зобов'язань держави щодо їх утвердження i захисту відбулася зміна пріоритетності функцій суду - від органу, що вирішує спір - контролює інші гілки влади - до інституції, що здійснює захист конституційних прав.

Ураховуючи генезис та становлення ідеї прав людини, пропонуємо виокремити такі етапи розвитку механізму судового захисту конституційних прав людини:

1. Перший етап охоплює період після буржуазних революцій (Декларація прав людини, Франція, Конституція США 1787). Саме тоді здійснюється визнання на національних рівнях основоположних прав, створюються національні режими судового захисту. Роль суду запобігти свавіллю, здійснюючи контроль за іншими гілками влади.

2. Другий етап розпочався після прийняття Загальної декларації прав людини 1948 року, Білля про права (Міжнародні пакти, низка Конвенцій, що регулюють окремі питання прав людини). У цей період відбулося закріплення на міжнародному рівні основоположних прав - держави взяли на себе ключові зобов'язання щодо прав людини: дотримуватися, сприяти, захищати. Виникає концепція ефективного засобу юридичного захисту. Створюється міжнародний режим судового захисту - система міжнародних судових та квазі-судових установ. Особливість міжнародного захисту полягає в контролі за 
виконанням державами своїх міжнародних зобов'язань відповідно до конвенцій. Паралельно відбувається імплементація міжнародних стандартів прав людини у національні конституції.

3. Третій етап пов'язаний зі становленням та розвитком регіональних режимів захисту прав людини: Європейського (створення Ради Європи, прийняття ЄКПЛ), Міжамериканського, Азійського, Африканського та охоплює період з початку 1950-х років. Для контролю за додержанням державами-учасницями вищезгаданих конвенцій своїх зобов'язань також створюються контролюючі судові органи: ЄСПЛ, Африканський суд із прав людини і народів, Міжамериканський суд із прав людини.

Ці судові установи не є черговими інстанціями після національних судів, на що неодноразово наголошували відповідні суди у своїх рішеннях. Так, наприклад, умовою для звернення до ЄСПЛ є вичерпання всіх національних засобів юридичного захисту, але тільки тих, які Судом буде визнано ефективними в розумінні статті 13 Конвенції. Тож правова природа цих судів полягає в тому, що ці суди слідкують за дотриманням державами-учасницями прав, гарантованих конвенціями та мають повноваження застосовувати заходи юридичного впливу на державупорушника. Якщо держава зазнає «failure» щодо виконання своїх зобов'язань із прав людини - лише в такому випадку регіональний механізм судового захисту може бути застосовано.

4. Четвертий етап пов'язаний з інтеграцією держав та створенням конституційних надпорядків, наприклад утворення Європейського Союзу. У зв'язку із цим виникає конкуренція юрисдикцій (між національними і наднаціональними судами, між ЄСПЛ та Судом ЄС, між конституційними судами та ЄСПЛ, Судом ЄС) ${ }^{4}$.

4 Детальніше див. М. Савчин. Порівняльне конституційне право: навчальний посібник. Київ : Юрінком Інтер, 2019, 328 с. 
Права людини в Україні та у зарубіжних країнах:

проблеми теорії та нормативно-правової регламентації

\section{2. Правова природа судового захисту прав людини}

Узагальнивши напрацювання філософії права, теорії права, конституційного права та прав людини, дослідивши міжнародні та національні нормативно-правові положення, що стосуються судового захисту, практику їх застосування, можна говорити про множинну природу категорії судового захисту.

Судовий захист як основоположне право. Зазначене право закладено в низці міжнародних документів з прав людини (статті 8-10 Загальної декларації прав людини, стаття 14 Міжнародного пакту про громадянські та політичні права, стаття 6 Європейської конвенції із прав людини, стаття 47 Хартії Основних прав ЄС тощо). Водночас це право $є$ i одним із найбільш «вразливих». Зокрема, як свідчить статистика рішень ЄСПЛ, близько 40\% порушень, констатованих судом, стосуються статті 6 Конвенції, а саме справедливого судового розгляду (16,86\%) та тривалості процедур (21,41\%) [33].

Положення щодо права на судовий захист знайшли відображення в національних конституціях та практиці конституційних судів. Так, Конституційний суд України в одному 3 рішень зазначає: «Конституційне право на судовий захист належить до невідчужуваних та непорушних. Кожен під час розгляду будь-якої справи, в тому числі кримінальної, щодо діяння, у вчиненні якого обвинувачується, має право на правосуддя, яке відповідало б вимогам справедливості» (абзац перший пункту 5 мотивувальної частини ) [18]. Право на судовий захист включає в себе, зокрема, можливість оскарження судових рішень в апеляційному та касаційному порядку, що $\epsilon$ однією з конституційних гарантій реалізації інших прав і свобод, захисту їх від порушень і протиправних посягань, в тому числі від помилкових і неправосудних судових рішень. (абзац дев'ятий підпункту 2.1 пункту 2 мотивувальної частини ) [19].

Деякі науковці також зазначають: «право на судовий захист - це передбачена законодавством можливість 
фізичних та юридичних осіб захищати свої права в судах загальної і конституційної юрисдикції. Це право слід розглядати двояко: 3 одного боку, як одне 3 конституційних прав людини в державі нарівні з іншими політичними, економічними, соціальними й культурними правами, а з іншого - як право, що закріплює спеціальний механізм захисту всіх без винятку вищезазначених прав» [3, с. 12]. Право на судовий захист також розглядається як «спосіб захисту прав, свобод і законних інтересів учасників суспільних правовідносин - фізичних та юридичних осіб» [25, с. 29]; «гарантований Конституцією правовий інструмент, за допомогою якого суб'єкти права можуть добитися відновлення порушеного права» [26, с. 4].

Судовий захист як гарантія основоположних прав. Як зазначає Управління Верховного комісара ОOH із прав людини у рекомендаціях державам щодо імплементації прав людини під час розроблення конституцій, «судова система лежить в основі гарантій прав людини. По-перше, суд захищає окрему особу чи групи осіб від свавільних дій держави, таких як позбавлення волі, експропріація без законних підстав та/або справедливої компенсації, або невиправдане позбавлення соціальних послуг. По-друге, судові органи надають окремим особам або групам осіб можливість переглядати i вирішувати їх справи незалежним, компетентним та неупередженим органом. По-третє, рішення судової влади, зокрема рішення, прийняті вищим апеляційним судом або конституційними судами, можуть впливати на державну політику та законодавство, наприклад, переглядаючи конституційність закону чи рішень або розглядаючи судові справи в інтересах суспільства. Отже, як міжнародне право в галузі прав людини, так і сучасний конституціоналізм надають великого значення праву на доступ до судів, праву на апеляцію та праву на конституційну скаргу» [31, с. 107].

Подібні ідеї містяться в низці рішень Конституційного суду України: «Судовий контроль за правомірністю порушення кримінальної справи $є$ дієвою гарантією прав і 
свобод людини і громадянина, що забезпечує реалізацію права особи на судовий захист та не допускає зловживань із боку посадових та службових осіб правоохоронних органів (абзаци перший, третій, четвертий підпункту 3.2 пункту 3 мотивувальної частини ); право на судовий захист $\epsilon$ конституційною гарантією прав і свобод людини i громадянина, а обов'язкове виконання судових рішень складовою права на справедливий судовий захист (абзац п'ятий підпункту 2.1 пункту 2 мотивувальної частини) [20]; право кожного на судовий захист є однією 3 конституційних гарантій реалізації інших прав і свобод, захисту їх від порушень i протиправних посягань (абзац четвертий підпункту 2.1 пункту 2 мотивувальної частини) [23].

Судовий захист як ефективний засіб правового захисту. Стаття 2 Міжнародного пакту про громадянські та політичні права зобов'язує держави забезпечити ефективний засіб захисту. Стаття 13 ЄКПЛ передбачає право на ефективний засіб правового захисту, зазначаючи, що «кожна людина, чиї права та свободи, визнані в цій Конвенції, були порушені, має право на ефективний засіб юридичного захисту в національному органі, навіть якщо таке порушення було вчинене особами, які виступають в якості офіційної особи». Це одне із ключових положень, що лежить в основі системи захисту прав людини Конвенції, поряд із вимогами статті 1 про зобов'язання поважати права людини і статті 46 про виконання рішень ЄСПЛ [6].

Право на ефективний засіб правового захисту також відображає основоположну роль національних судових систем для системи Конвенції, якщо профілактичні заходи виявилися недостатніми. У цьому відношенні слід зазначити, що, на додаток до зобов'язання констатувати існування ефективних засобів правового захисту у світлі прецедентного права Суду, держави несуть загальний обов'язок щодо вирішення проблем, що лежать в основі порушень, знайдені в рішеннях Суду [14]. 
Судовий захист як механізм захисту прав людини. Право на судовий захист може виступати одночасно як правомгарантією, так і механізмом реалізації обов'язку держави гарантувати права і свободи громадян, які закріплені в Конституції, законах і передбачені міжнародними зобов'язаннями держави, що визнається одним із найбільш ефективних засобів захисту прав людини. Судовий захист серед усього спектру юридичних гарантій є основним, що зумовлено юридичною природою судової гілки влади, місцем суду $\mathrm{y}$ структурі державних органів, його функціональним призначенням [11].

На думку Конституційного суду України, забезпечення прав i свобод потребує, зокрема, законодавчого закріплення механізмів (процедур), які створюють реальні можливості для здійснення кожним громадянином прав і свобод (абзац четвертий підпункту 3.2 пункту 3 мотивувальної частини Рішення Конституційного Суду України від 24 грудня 2004 року № 22-рп/2004). До таких механізмів належить структурована система судів і види судового провадження, встановлені державою (речення друге - четверте абзацу першого підпункту 3.2 пункту 3 мотивувальної частини ) [21]. Судовий захист прав і свобод людини i громадянина необхідно розглядати як вид державного захисту прав і свобод людини і громадянина, i саме держава бере на себе такий обов'язок відповідно до частини другої статті 55 Конституції України [22]. Більше того, у правовій державі звернення до суду $\epsilon$ універсальним механізмом захисту прав, свобод та законних інтересів фізичних і юридичних осіб (абзац п'ятий підпункту 2.2 пункту 2 мотивувальної частини ) [16].

\section{3. Особливості механізму судового захисту конституційних прав людини}

Під захистом (прав) зазвичай розуміють цілісну систему правових форм, заходів та засобів, взаємодія яких направлена на утвердження або відновлення порушених прав і свобод людини і громадянина Таким чином, режим 
захисту прав людини активізується у випадку їх порушення [8, с.48]. У свою чергу, механізм захисту конституційних прав i свобод можна визначити як сукупність взаємопов'язаних процесів, елементів, а також зв'язків між ними, які виконують функцію реагування на порушення конституційних прав і свобод (реагування, у свою чергу, включає застосування правових засобів для припинення порушення, відновлення порушеного права, застосування заходів юридичної відповідальності тощо).

Наразі можна говорити про існування двох моделей захисту конституційних прав людини залежно від порядку та суб'єктів здійснення функції захисту: судової та позасудової. Судовий захист реалізується спеціально створеним органом - судом, який у процесі здійснення правосуддя виконує, в тому числі, функцію захисту прав людини. Позасудовий механізм передбачає захист в адміністративному порядку (в порядку діяльності суб'єктів публічної адміністрації), через звернення до національних правозахисних інституцій, або в порядку самозахисту тощо.

Таким чином, судовий захист конституційних прав людини є однією з моделей захисту конституційних прав людини в межах загальної системи захисту прав людини, що виступає гарантією виконання державами своїх зобов'язань щодо захисту прав людини. У зв'язку із цим абсолютно логічним видається те, чому держава несе відповідальність не лише у випадку безпосереднього порушення права, але i коли таке порушення було заподіяно у зв'язку з невиконанням рішення суду чи тривалою судовою процедурою. Хоча судова влада i $\epsilon$ незалежною гілкою влади, а гарантія незалежності $\epsilon$ ключовою в забезпеченні права на судовий захист, держава все ж відповідає за належну організацію судової системи і системи правосуддя таким чином, щоб належно i ефективно реалізувати свою функцію захисту.

Цю тезу однак слід сприймати з деяким застереженням. Незважаючи на те, що захист прав людини i основоположних свобод $€$ однією з функцій держави, 
власне механізм судового захисту конституційних прав не обмежується виключно державою чи національними механізмами. Навпаки, для того, щоб контролювати дотримання державою її універсальних зобов'язань щодо прав людини, створено розгалужену мережу наднаціональних інституцій, у тому числі і судових.

Ураховуючи викладене, механізм судового захисту конституційних прав і свобод можна визначити як систему (сукупність взаємопов'язаних процесів, елементів, а також зв'язків між ними), що забезпечує захист і відновлення судом конституційних прав людини.

Виходячи 3 функцій механізму судового захисту конституційних прав і свобод, можливо виокремити такі його сутнісні ознаки.

По-перше, ми поділяємо думку тих науковців, які пропонують розглядати механізм захисту прав людини в контексті «режимів», у межах яких він функціонує. Режим можна розтлумачити як систему механізмів, інституцій, нормативних та організаційних інструментів, що виконують правозахисну функцію [9]. Так, доцільним видається виокремити національний (в межах держави), регіональний (в межах регіональних систем захисту прав людини: Європейська (система Ради Європи та Європейського Союзу), Міжамериканська, Африканська тощо) та міжнародний (система ОOH, інших міжнародних організацій) режими функціонування механізму судового захисту конституційних прав людини.

По-друге, механізм судового захисту конституційних прав і свобод людини має два взаємозалежні аспекти: матеріальний (норми права, на основі яких механізм функціонує) та процесуальний (власне процедура функціонування механізму). Перший аспект дає відповідь на питання, що саме та за яких умов має бути здійснено у випадку порушення конституційного права, другий (процесуальний) аспект описує, яким чином має бути здійснено реагування у випадку порушення конституційного права. 
По-третє, в межах механізму судового захисту конституційних прав є, як мінімум, 3 суб'єкти: суб'єкт, конституційне право якого порушено; суб'єкт, який порушив відповідне право; суб'єкт реагування (суд). Суб'єкт реагування на порушення має бути наділений відповідними повноваженнями, мати у своєму розпорядженні ресурси для здійснення функції захисту та діяти в межах чітко визначеної процедури. Окрім того, для суб'єкта, наділеного конституційними правами, необхідно забезпечити відповідні інструменти звернення до суб'єкта реагування та поінформованість про порядок використання таких інструментів, а для суб'єкта реагування - інструменти припинення порушення, відновлення права та притягнення порушника до відповідальності. Складовими частинами судового механізму захисту конституційного права також слід визначити: гарантії конституційних прав i свобод (нормативні та інституційні), а також гарантії незалежності суду, правові засоби, спрямовані на відновлення порушеного права, застосування заходів юридичної відповідальності та відшкодування шкоди за порушення конституційного права.

\section{Висновки}

Судовий захист доцільно розглядати як одну з моделей захисту конституційних прав людини через призму виконання державою своїх універсальних зобов'язань захищати права людини (визначених міжнародними, регіональними стандартами 3 прав людини та національними конституціями). Саме такий підхід повною мірою ілюструє роль держави щодо забезпечення ефективної, незалежної судової системи, яка, з одного боку, забезпечує реалізацію основоположного права на доступ до суду, а з іншого - $є$ інституційною гарантією для інших основоположних прав людини. 
Виникнення, становлення та розвиток механізму судового захисту конституційних прав людини слід пов'язувати із процесом виникнення національних, регіональних та міжнародних режимів захисту прав людини та в контексті універсалізації обов'язків держави щодо прав людини: позитивних (утверджувати, захищати) та негативних (утримуватися від порушень). У свою чергу, саме 3 обов'язком держави захищати права людини i пов'язують існування судового механізму захисту конституційних прав і свобод.

Відтак у зв'язку зі зміною розуміння прав людини та зобов'язань держави щодо їх утвердження i захисту відбулася зміна пріоритетності функцій суду - від органу, що вирішує спір - контролює інші гілки влади - до інституції, що здійснює захист конституційних прав.

Ураховуючи генезис та становлення ідеї прав людини, пропонуємо розглядати такі етапи розвитку механізму судового захисту конституційних прав людини: перший етап, який охоплює період після буржуазних революцій (роль суду - запобігти свавіллю, здійснюючи контроль за іншими гілками влади); другий етап, пов'язаний із прийняттям ключових міжнародних документів у сфері прав людини (створюється міжнародний режим судового захисту - система міжнародних судових та квазі-судових установ); третій етап, що пов'язаний зі становленням та розвитком регіональних режимів захисту прав людини, та четвертий етап, ознаменований інтеграцією держав та створенням конституційних надпорядків (Європейський Союз).

Правова природа судового захисту конституційних прав людини характеризується множинністю. Так, у теорії, філософії права судовий захист розглядається як основоположне право; гарантія основоположних прав; ефективний засіб захисту; механізм захисту прав людини. Водночас механізм судового захисту конституційних прав і свобод пропонуємо визначити як систему (сукупність взаємопов'язаних процесів, елементів, а також зв'язків між 
ними), що забезпечує захист і відновлення судом конституційних прав людини.

До основних ознак механізму судового захисту конституційних прав нами віднесено такі: реалізація спеціально створеним органом - судом, який в процесі здійснення правосуддя виконує, в тому числі, функцію захисту прав людини; функціонування в межах «режимів» (національний, регіональний, міжнародний); існування двох взаємозалежних аспектів згаданого механізму: матеріального (норми права, на основі яких механізм функціонує) та процесуального (власне процедура функціонування механізму); особливість суб'єктного складу та наявність гарантій.

Ураховуючи стрімкий розвиток технологій та глобалізаційних процесів, перспективними, на нашу думку, $\epsilon$ подальші напрями дослідження механізму судового захисту конституційних прав з огляду на його подальшу трансформацію у зв'язку 3 інтеграцією в межах європейського простору, а також у контексті цифровізації доступу до правосуддя.

\section{Список використаних джерел:}

1. Бігун В.С. Філософія правосуддя: ідея та здійснення : монографія. Київ, 2011. 303 с.

2. Висновок № 1 (2001) Консультативної ради європейських суддів для Комітету міністрів Ради Європи про стандарти незалежності судових органів та незмінюваність суддів. URL: https://zakon.rada.gov.ua/laws/ show/994_a52.

3. Дашутін I.В. Правове регулювання судового захисту трудових прав громадян : автореф. дис... канд. юрид. наук : 12.00.05 / Національна юридична академія України ім. Ярослава Мудрого. Хаків, 2008. 20 с.

4. Дослідження практики Європейського суду з прав людини для визначення Національних стандартів компенсацій порушення державою прав людини : [інформаційно-аналітичний звіт] / M. Гнатовський, 
А. Федоров, К. Красовський, О. Власенкова. Київ : Атіка, 2011 p. 184 c.

5. История западной философии [B 2 т.] T. II, кн. 3 / Бертран Рассел; [перевод с английского]. Москва : Издательство АСТ, 2018. 512 c.

6. Керівництво з належної практики щодо національних засобів правового захисту (ухвалено Комітетом Міністрів 18 вересня 2013 року), Рада Європи, 2013 рік. URL: https://rm.coe.int/k-/1680695aab.

7. Кочура Е. Понятие и элементы конституционноправового механизма защиты прав и свобод человека и гражданина. Legea şi viaţa. 2015. № 4/2(280). C. 47-52.

8. Малишев Б. В. Судовий прецедент у правовій системі Англії. Київ : Юридична думка, 2008. 303 с.

9. Манукян В.И. Международная защита прав человека: право, прецеденты, комментарии : Научно-практическое пособие. Киев : Истина, 2010. 480 с.

10. Міжнародний пакт про громадянські та політичні права. URL: https://zakon.rada.gov.ua/laws/show/995_043.

11. Остапенко В.В. Гарантії суб'єктивних прав і свобод як елемент правового статусу людини і громадянина. Теорія і практика правознавства. 2018. Вип. 1(13).

12. Отфрид Гьоффе. Трансцендентальний обмін фігура легітимації прав людини? Філософія прав людини / За редакції Ш. Госепата та Г. Ломанна ; пер. з нім. О. Юдіна та Л. Доронічевої. Київ : Ніка-Центр, 2016. 320 с.

13. Рекецька I.P. Судова влада в контексті демократичної трансформації українського суспільства : автореф. дис...канд. політ. наук : 23.00 .02 / Одеська національна юридична академія. Одеса, 2003.16 с.

14. Рекомендація Rec (2004) 6 Комітету міністрів Ради Європи державам-членам «Щодо вдосконалення національних засобів правового захисту». URL: https://zakon.rada.gov.ua/laws/show/994_718.

15. Рішення Конституційного Суду України у справі за конституційним зверненням акціонерної компанії 
«Харківобленерго» щодо офіційного тлумачення положень пункту 2 частини другої статті 17, пункту 8 частини першої статті 26, частини першої статті 50 Закону України «Про виконавче провадження» від 26 червня 2013 року № 5-рп/2013. Вісник Конституційного Суду України від 2013. № 4. C. 17.

16. Рішення Конституційного Суду України у справі за конституційним зверненням громадянина Трояна Антона Павловича щодо офіційного тлумачення положень статті 24 Конституції України (справа про рівність сторін судового процесу) від 12 квітня 2012 року № 9-рп/2012. Вісник Конституційного Суду України від 2012 р. № 3. С. 41.

17. Рішення Конституційного Суду України у справі за конституційним поданням Уповноваженого Верховної Ради України 3 прав людини щодо відповідності Конституції України (конституційності) положення третього речення частини першої статті 13 Закону України «Про психіатричну допомогу» (справа про судовий контроль за госпіталізацією недієздатних осіб до психіатричного закладу) від 1 червня 2016 року № 2-рп/2016. Вісник Конституційного Суду України від 2016, № 6. С. 60.

18. Рішення Конституційного Суду України у справі за конституційним поданням Верховного Суду України щодо відповідності Конституції України (конституційності) положень статті 69 Кримінального кодексу України (справа про призначення судом більш м'якого покарання) від 2 листопада 2004 року 15-рп/2004. Голос України від 11.01.2005. № 3.

19. Рішення Конституційного Суду України у справі за конституційним поданням Уповноваженого Верховної Ради України 3 прав людини щодо відповідності Конституції України (конституційності) положень частини другої статті 171-2 Кодексу адміністративного судочинства України від 8 квітня 2015 року № 3-рп/2015. Вісник Конституційного Суду України від 2015. № 3. С. 28.

20. Рішення Конституційного Суду України у справі за конституційним поданням Верховного Суду України щодо 
відповідності Конституції України (конституційності) положень частин сьомої, дев'ятої, пункту 2 частини шістнадцятої статті 236-8 Кримінально-процесуального кодексу України від 30 червня 2009 року № 16-рп/2009. Вісник Конституційного Суду України від 2009 р. № 5. С. 6.

21. Рішення Конституційного Суду України у справі за конституційним поданням Верховного Суду України щодо відповідності Конституції України (конституційності) положень Закону України «Про внесення змін до деяких законодавчих актів України щодо підвідомчості справ, пов'язаних із соціальними виплатами» від 9 вересня 2010 року № 19-рп/2010. Вісник Конституиійного Суду України від 2010 р. № 5. С. 25.

22. Рішення Конституційного Суду України у справі за конституційним поданням Президента України щодо офіційного тлумачення положень частин другої, третьої статті 124 Конституції України (справа щодо підвідомчості актів про призначення або звільнення посадових осіб) від 7 травня 2002 року № 8-рп/2002. Вісник Конституційного Суду України від 2002 р. № 2. С. 29.

23. Рішення Конституційного Суду України у справі за конституційними поданнями Верховного Суду України щодо відповідності Конституції України (конституційності) положень частини третьої, абзаців першого, другого, четвертого, шостого частини п'ятої статті 141 Закону України «Про судоустрій і статус суддів» та положень пункту 5 розділу III «Прикінцеві положення» Закону України «Про внесення змін до деяких законодавчих актів України щодо пенсійного забезпечення» (справа про щомісячне довічне грошове утримання суддів у відставці) від 8 червня 2016 року № 4-рп/2016. Вісник Конституційного Суду України від 2016 р. № 6. С. 97.

24. Савчин М.В. Порівняльне конституційне право: навчальний посібник. Київ : Юрінком Інтер, 2019. 328 с.

25. Сірий М.I. Право на судовий захист. Юридична енциклопедія / ред. Ю.С. Шемшученко [та ін.] ; НАН України, Ін-т держави і права ім. В.М. Корецького. Київ : Вид-во 
«Українська енциклопедія» ім. М.П. Бажана, 1998. Т. 5 : П-С. Київ : [б.в.], 2003. 736 с.

26. Тимченко Г.П. Способи та процесуальні форми захисту цивільних прав : автореф. дис... канд. юрид. наук : 12.00 .03 ; Нац. юрид. акад. України ім. Я. Мудрого. Харків, 2002. $20 \mathrm{c}$.

27. Філософія прав людини / За редакції Ш. Госепата та Г. Ломанна ; Пер. $з$ нім. О. Юдіна та Л. Доронічевої. Київ : Ніка-Центр, 2016. Серія «Зміна парадигми», Вип. 13. 320 с.

28. Філософія свободи / Ларс Фр. Г. Свендсен ; пер. 3 норвезьк. Львів : Видавництво Аннети Антоненко ; Київ : Ніка-Центр, 2016. 336 с.

29. Brian Z. Tamanaha. On the Rule of Law: History, Politics, Theory. NY, Cambridge University Press, 2009.180 p.

30. Déclaration des droits de l'Homme et du citoyen de 1789. URL: http://www.textes.justice.gouv.fr/textesfondamentaux-10086/droits-de-lhomme-et-libertesfondamentales-10087/declaration-des-droits-de-lhomme-etdu-citoyen-de-1789-10116.html.

31. Human Rights and Constitution Making. United Nations publication issued by the Office of the United Nations High Commissioner for Human Rights (OHCHR), 2018. URL: https://www.ohchr.org/Documents/Publications/Constitution Making_EN.pdf.

32. Jayawickrama N.. The Judicial Application of Human Rights Law: National, Regional and International Jurisprudence. Cambridge : Cambridge University Press. 965 p.

33. Overview 1959-2019. European Court of Human Rights, February 2020. URL: https://www.echr.coe.int/Documents/ Overview_19592019_ENG.pdf.

34. Vienna Declaration and Programme of Action, adopted by the World Conference on Human Rights in Vienna on 25 June 1993. URL: https://www.ohchr.org/en/professionalinterest/ pages/vienna.aspx. 